\title{
The role of $k$-opioid receptor activation in mediating antinociception and addiction
}

\author{
Yu-hua WANG ${ }^{1,2}$, Jian-feng $\mathrm{SUN}^{2}$, Yi-min $\mathrm{TAO}^{2}$, Zhi-qiang $\mathrm{CHI}^{2}$, Jing-gen $\mathrm{LIU}^{2,}$ * \\ ${ }^{1}$ School of Pharmacy, Nanjing University of Chinese Medicine, Nanjing 210046, China; ${ }^{2}$ State Key Laboratory of Drug Research, \\ Shanghai Institute of Materia Medica, Chinese Academy of Sciences, Shanghai 201203, China
}

\begin{abstract}
The K-opioid receptor (KOR), a member of the opioid receptor family, is widely expressed in the central nervous system and peripheral tissues. Substantial evidence has shown that activation of KOR by agonists and endogenous opioid peptides in vivo may produce a strong analgesic effect that is free from the abuse potential and the adverse side effects of $\mu$-opioid receptor (MOR) agonists, such as morphine. In addition, activation of the KOR has also been shown to exert an inverse effect on morphine-induced adverse actions, such as tolerance, reward, and impairment of learning and memory. Therefore, the KOR has received much attention in the effort to develop alternative analgesics to MOR agonists and agents for the treatment of drug addiction. However, KOR agonists also produce several severe undesirable side effects such as dysphoria, water diuresis, salivation, emesis, and sedation in nonhuman primates, which may limit the clinical utility of KOR agonists for pain and drug abuse treatment. This article will review the role of KOR activation in mediating antinociception and addiction. The possible therapeutic application of k-agonists in the treatment of pain and drug addiction is also discussed.
\end{abstract}

Keywords: K-opioid receptor; dynorphin; desensitization; antinociception; tolerance; addiction; drug withdrawal; cocaine reward; negative mood state

Acta Pharmacologica Sinica (2010) 31: 1065-1070; doi: 10.1038/aps.2010.138; published 23 Aug 2010

\section{Introduction}

Pharmacological studies have established the existence of two types of $\mathrm{k}$-opioid receptor (KOR). One subtype of KOR, $\mathrm{k} 1$, binds U69593 with a high affinity, whereas the $\kappa 2$ subtype binds this drug with a low affinity ${ }^{[1]}$. A naloxone benzoylhydrazone sensitive KOR subtype ( $\mathrm{k} 3$ ) has also been proposed but not been fully confirmed by sufficient evidence ${ }^{[2-4]}$. So far only KOR1 has been cloned in human and rodents ${ }^{[4,5]}$. KORs are coupled to heterotrimer $\mathrm{Gi} /$ o proteins. Activation of KORs leads to an inhibition of adenylyl cyclase through the Ga subunit and induces increased potassium channel conductance and decreased calcium conductance via the $G \beta \gamma$ subunit $^{[6]}$. Modulation of these ion channels by KORs in neurons results in decreased action potential generation and neurotransmitter release. Stimulation of KORs has also been shown to activate ERK (extracellular regulated kinase), JNK (c-Jun N-terminal kinase), and p38 MAPK (mitogen-activated protein kinase) signal transduction cascades ${ }^{[7-13]}$. Addition-

\footnotetext{
* To whom correspondence should be addressed.

E-mail jgliu@mail.shcnc.ac.cn

Received 2010-05-31 Accepted 2010-07-20
}

ally, there is evidence that activation of KORs stimulates $\mathrm{Na}-\mathrm{H}$ exchanger-3 activity via $\mathrm{Na}^{+}-\mathrm{H}^{+}$-exchanger regulatory factor-1/Ezrin-radixin-moesin-binding phosphoprotein-50, independent of pertussis toxin-sensitive G proteins ${ }^{[14]}$. After repeated or sustained exposure to agonists, KORs are desensitized by receptor phosphorylation and recruitment of $\beta$-arrestin and endocytosed via a clathrin-and dynamin-dependent pathway. These internalized receptors either return to the membrane by dephosphorylation and EBP50/NHERF-1dependent recycling or are degraded via both lysosome and proteasome systems ${ }^{[15,16]}$. G-protein receptor kinase 3 (GRK3) and $\beta$-arrestin $1 / 2$ play important roles in the modulation of KOR trafficking ${ }^{[12,17]}$.

KORs are widely expressed throughout the brain, spinal cord, and peripheral tissues ${ }^{[7]}$. High levels of KOR mRNA have been detected in the ventral tegmental area (VTA), nucleus accumbens (NAc), prefrontal cortex (PFC), hippocampus, striatum, amygdala, locus coeruleus (LC), substantia nigra (SN), dorsal raphe nucleus (DRN) and hypothalamus of both the rat and human brains ${ }^{[5,18-20]}$. These brain areas are implicated in the modulation of reward, mood state and cognitive function. KORs are also expressed at several 
levels of pain circuitry, including areas such as the dorsal root ganglia, dorsal spinal cord, rostral ventromedial medulla, periaqueductal gray (PAG), sensory thalamus and the limbic regions ${ }^{[12,21-23]}$. Activation of KORs in vivo produces many effects including analgesia, dysphoria, water diuresis, corticosteroid elevations, immunomodulation, decreases in pilocarpine-induced seizure and associated mossy fiber sprouting and hilar neuron loss ${ }^{[16]}$. KOR agonists have attracted considerable attention for their ability to exert potent analgesic effects without high abuse potential ${ }^{[24-27]}$ and antagonize various MOR-mediated actions in the brain, including analgesia, tolerance, reward and memory processes ${ }^{[28]}$.

\section{The role of the k-opioid system in the modulation of antinociception and drug addiction}

The K-opioid system consists of the dynorphin family of neuropeptides and KORs ${ }^{[29,30]}$. Dynorphins (Dyns) are composed of seven peptides of varying lengths that are formed from the precursor prodynorphin (PDyn; see Schwarzer, $\left.2009^{[31]}\right)$. They are released from the presynaptic terminal of depolarized PDyn-containing neurons following sequential enzymatic cleavage, mainly by proprotein convertase- $2^{[32,33]}$. The Dyn/KOR system can mediate antinociception and drug reward through presynaptic and postsynaptic modulation of the levels of several neurotransmitters such as dopamine (DA), $\gamma$-Aminobutyric acid (GABA) and glutamate ${ }^{[19,34]}$. It has been well established that the Dyn/KOR system exerts an inhibitory effect on brain reward function by suppressing DA release from the mesolimbic reward pathway and the nigrostriatal pathway ${ }^{[4,35-38]}$. These brain regions are intimately associated with the development of drug dependence. Numerous studies in both nonhuman primates and rats have demonstrated that $\mathrm{K}$-agonists functionally attenuate many behavioral effects of cocaine, including behavioral sensitization ${ }^{[39,40]}$ place preference $^{[40-42]}$, and self-administration ${ }^{[43-46]}$. Administration of K-agonists also attenuates the reinstatement of extinguished drug-taking behavior in an animal model of relapse ${ }^{[46,47]}$. These inhibitory effects of $\mathrm{k}$-agonists on cocaine-induced abuse-related behaviors are possibly achieved by inhibiting the release of DA from dopaminergic neurons ${ }^{[37,48]}$.

A role for KORs in pain circuits has been widely described in both the central and peripheral nervous systems. Although it has been reported that KOR activation antagonizes MOR-mediated analgesia, numerous studies have documented potent antinociceptive effects after intrathecal and systemic administration of selective $\mathrm{K}$-agonists ${ }^{[49-52]}$. Moreover, $\mathrm{K}$-opioid agonists are free from the abuse potential and adverse side effects of $\mu$-agonists such as morphine ${ }^{[24-27]}$. Additionally, pharmacologic studies in KOR and PDyn knockout mice indicate important roles for KORs in mediating inhibition of visceral, chemical, inflammatory and thermal pain ${ }^{[12,53,54]}$. Peripherally selective $\mathrm{K}$-agonists (including the peptide K-agonists ${ }^{[55]}$ ) act as particularly potent analgesics after systemic administration in a wide variety of visceral-pain and inflammatory-pain models as well as in thermal hyperalgesia induced by capsaicin. Moreover, the analgesic potency of $\mathrm{K}$-agonists is enhanced under inflammatory conditions ${ }^{[56-6]}$. Both central and peripheral sites of action may contribute to these endpoints ${ }^{[62-64]}$.

\section{The role of the k-opioid system in modulation of the aversive effects of stress and drug relapse}

Although accumulating evidence demonstrates that KOR agonists produce potent analgesic effects and suppress drug reward, these agonists have also been shown to produce aversive mood and facilitate drug relapse ${ }^{[7]}$. For example, KOR activation produces dysphoria (defined here as an unpleasant or aversive state) in humans ${ }^{[65,66]}$ and pro-depressionlike behaviors (eg, anhedonia, dysphoria, and anxiety) in rodents ${ }^{[67-70]}$. Moreover, the aversive effects of KOR agonists have also been characterized extensively in rodents using place conditioning paradigms, where they establish conditioned place aversions (CPAs) after systemic administration $^{[30,41,71-73]}$ or microinfusion into the mesocorticolimbic DA system $^{[67,74]}$. In addition, stimulation of KORs with selective agonist can cause a Dyn/KOR-dependent reinstatement of extinguished cocaine CPP (conditioned place preference) or drug self-administration ${ }^{[75-78]}$. These reports suggest that activation of the Dyn/KOR system is likely to play a major role in stress-induced reinstatement and that blockade of KOR receptors with selective antagonists may be a useful and powerful therapeutic strategy for protecting individuals from relapse to drug abuse. Furthermore, the fact that KOR function appears to have a profound influence on behaviors that are thought to reflect motivational and emotional states in animal models suggests that KORs might represent a viable target for psychiatric medications. An application of KOR antagonists is in the treatment of depressive and anxiety-related disorders, both of which are triggered or exacerbated by stress ${ }^{[12]}$.

\section{Potential therapeutic applications of k-opioid agonists in pain relief and drug addiction treatment} Potential therapeutic applications in pain relief

Although MOR agonists are still regarded as the gold standard to relieve severe pain, their therapeutic utility is limited by the tendency to cause addiction following repeated or prolonged administration. Because KOR agonists can exert potent analgesic effects and suppress the drug reward response, they were initially expected to be used as non-addictive analgesics. However, in clinical trials ${ }^{[51,56]}$, selective $\mathrm{K}$-agonists that freely enter the central nervous system (eg, ICI199441, enadoline, and spiradoline) have been shown to produce unpleasant central side effects, such as dysphoria, sedation and diuresis. As a result, there has been an attempt to develop peripherally selective $\mathrm{K}$-agonists ${ }^{[51]}$ and mixed $\mathrm{k} / \mu$-agonists ${ }^{[79-81]}$ in the hopes of developing strong analgesics devoid of central side effects. Synthetic K-agonists, as well as Dyn A, have been reported to reduce morphine tolerance in a variety of antinociceptive tests ${ }^{[80,82,83]}$. Although the endogenous Dyns, Dyn A analogs (eg, E2078) and other peptide K-agonists (eg, CR665 and CR845) have several advantages such as high activity, high specificity and low toxicity, the delivery of peptides as therapeutic agents remains a challenge due to their metabolic 
instability ${ }^{[5]}$. Currently, peripherally selective $\mathrm{k}$-agonists (including the peptide $\mathrm{K}$-agonists ${ }^{[55]}$ ) are under development as new analgesics due to their lack of central side effects such as respiratory depression, nausea, sedation, dysphoria, addiction and analgesic tolerance ${ }^{[51,56]}$. Nevertheless, none have thus far been approved for use as analgesics. The popular analgesics available today are still classical compounds with mixed $\mathrm{K}$ - and $\mu$-activity such as pentazocine, butorphanol and nalbuphine ${ }^{[81]}$. Cyclazocine and morphinan derivatives are novel $\mathrm{k}$-agonists with additional $\mu$-activity, which have attracted much recent attention for their ability to inhibit antinociceptive tolerance and cocaine-reinforced responding with fewer undesirable side effects ${ }^{[79,80]}$.

\section{Potential therapeutic applications in the treatment of drug addic-} tion

Drug addiction is a disorder characterized by chronic relapse, which is accompanied by the compulsion to seek and take the drug, loss of control in limiting intake and emergence of a negative emotional state (eg, dysphoria, anxiety, irritability) when access to the drug is prevented ${ }^{[84]}$. The addiction cycle is composed of three stages: binge/intoxication, withdrawal/ negative affect and preoccupation/anticipation. Additionally, the withdrawal symptoms after removal of chronic drug administration include signs of physical dependence and negative emotional state (dysphoria, anxiety and irritability) ${ }^{[84]}$. It has been demonstrated that $\mathrm{K}$-agonists can attenuate opiate withdrawal symptoms both in opiate-dependent animals and in humans ${ }^{[28,53,55,82,85-87]}$. This attenuation may be due to K-agonists possibly preventing drug withdrawal by inhibiting glutamatergic, GABAergic, or noradrenergic transmission in brain sites that mediate negative mood states such as the central nucleus of the amygdala $(\mathrm{CeA})$ or bed nucleus of the stria terminalis (BNST) ${ }^{[4]}$.

A wealth of studies indicates that $\mathrm{K}$-agonists can antagonize cocaine-induced alterations in behavior and brain chemistry ${ }^{[34,88]}$. Several studies have demonstrated that $\mathrm{K}$-agonists are effective at decreasing the rate of cocaine selfadministration both in humans and in animal models ${ }^{[43,46,47,89,90]}$. Also, K-agonists attenuate the development and long-term expression of cocaine-induced behavioral sensitization following their repeated, intermittent administration ${ }^{[01]}$. These effects most likely result from the inhibition of limbic DA release after acute administration of $\mathrm{K}$-agonists ${ }^{[34,88,92,93]}$. However, there is paradoxical evidence that continuous or prior exposure to $\mathrm{K}$-agonists can potentiate the rewarding effects of cocaine under stress conditions and stress-induced reinstatement $^{[36,94,95]}$. This evidence suggests that selective antagonists of KOR may represent useful and powerful therapeutic treatments for protecting individuals from relapse to drug abuse.

A growing number of preclinical studies have demonstrated that nonselective $\mathrm{K}$-agonists with additional activity at MORs can decrease cocaine self-administration with fewer side effects than highly selective $\mathrm{K}^{-a g o n i s t s}{ }^{[44,79,80,96-98]}$, indicating that mixed-action $\mathrm{\kappa} / \mu$-agonists may have particular utility for the treatment of drug abuse. Taken together, the majority of these findings indicate that $\mathrm{K}$-agonists antagonize both the behavioral and neurochemical effects of cocaine. The administration of $\mathrm{K}$-agonists can functionally attenuate behavioral effects of cocaine, including CPP, self-administration and behavioral sensitization. These inhibitory effects of $\mathrm{K}$-agonists on abuse-related behaviors are possibly achieved by suppressing DA release. Additionally, compounds with mixed $\mathrm{k}-$ and $\mu$-activity may be more promising candidate pharmacotherapies for drug abuse than selective K-agonists. However, there is evidence that KOR agonists produce aversive mood and facilitate drug relapse. Therefore, further studies are needed to confirm the utility of $\mathrm{k}$-agonists in the treatment of substance abuse.

\section{Conclusions and therapeutic perspectives}

Data from cell culture, experimental animals and humans have provided cellular, neurochemical, and behavioral evidence that KOR activity plays a key role in mediating antinociception, drug withdrawal symptoms and cocaine reward responses. Thus, $\mathrm{k}$-agonists are likely to become analgesics or even anti-addiction drugs without tolerance and dependence development following chronic drug exposure. Moreover, for the peripherally selective $\mathrm{K}$-agonists, their ability to exert potent analgesic effects in a variety of visceral pain conditions without presenting central side effects suggest a bright drug development future. Additionally, mixed-action $\mathrm{k}-/$ $\mu$-agonists may have promising uses for the treatment of pain or drug abuse with few side effects. However, all these predicted therapeutic applications require further study.

\section{Acknowledgements}

This work was supported by the National Basic Research Program grant from the Ministry of Science and Technology of China (No 2009CB522000, 2009ZX09301-001), National Natural Science Fundation of China (30873050) and a fund granted by the Chinese Academy of Sciences (KSCX2-YW-R-253).

\section{References}

1 Zukin RS, Eghbali M, Olive D, Unterwald EM, Tempel A. Characterization and visualization of rat and guinea pig brain kappa opioid receptors: evidence for kappa 1 and kappa 2 opioid receptors. Proc Natl Acad Sci USA 1988; 85: 4061-5.

2 Clark JA, Liu L, Price M, Hersh B, Edelson M, Pasternak GW. Kappa opiate receptor multiplicity: evidence for two U50,488-sensitive kappa 1 subtypes and a novel kappa 3 subtype. J Pharmacol Exp Ther 1989; 251: 461-8.

3 Connor M, Kitchen I. Has the sun set on kappa3-opioid receptors? $\mathrm{Br}$ J Pharmacol 2006; 147: 349-50.

4 Bruijnzeel AW. kappa-Opioid receptor signaling and brain reward function. Brain Res Rev 2009; 62: 127-46.

5 Simonin F, Gaveriaux-Ruff C, Befort K, Matthes H, Lannes B, Micheletti $\mathrm{G}$, et al. kappa-Opioid receptor in humans: cDNA and genomic cloning, chromosomal assignment, functional expression, pharmacology, and expression pattern in the central nervous system. Proc Natl Acad Sci USA 1995; 92: 7006-10.

6 Dhawan BN, Cesselin F, Raghubir R, Reisine T, Bradley PB, Portoghese PS, et al. International Union of Pharmacology. XII. Classification of 
opioid receptors. Pharmacol Rev 1996; 48: 567-92.

7 Bruchas MR, Land BB, Chavkin C. The dynorphin/kappa opioid system as a modulator of stress-induced and pro-addictive behaviors. Brain Res 2010; 1314: 44-55.

8 Bruchas MR, Macey TA, Lowe JD, Chavkin C. Kappa opioid receptor activation of p38 MAPK is GRK3- and arrestin-dependent in neurons and astrocytes. J Biol Chem 2006; 281: 18081-9.

9 Bruchas MR, Yang T, Schreiber S, Defino M, Kwan SC, Li S, et al. Long-acting kappa opioid antagonists disrupt receptor signaling and produce noncompetitive effects by activating c-Jun N-terminal kinase. J Biol Chem 2007; 282: 29803-11.

10 McLennan GP, Kiss A, Miyatake M, Belcheva MM, Chambers KT, Pozek JJ, et al. Kappa opioids promote the proliferation of astrocytes via Gbetagamma and beta-arrestin 2-dependent MAPK-mediated pathways. J neurochem 2008; 107: 1753-65.

11 Camilleri M. Novel pharmacology: asimadoline, a kappa-opioid agonist, and visceral sensation. Neurogastroenterol Motil 2008; 20 : 971-9.

12 Knoll AT, Carlezon Jr. Dynorphin, stress, and depression. Brain Res 2010; 1314: 56-73.

13 Belcheva MM, Clark AL, Haas PD, Serna JS, Hahn JW, Kiss A, et al. $\mathrm{Mu}$ and kappa opioid receptors activate ERK/MAPK via different protein kinase $\mathrm{C}$ isoforms and secondary messengers in astrocytes. J Biol Chem 2005; 280: 27662-9.

14 Huang P, Steplock D, Weinman EJ, Hall RA, Ding Z, Li J, et al. kappa Opioid receptor interacts with $\mathrm{Na}(+) / \mathrm{H}(+)$-exchanger regulatory factor-1/Ezrin-radixin-moesin-binding phosphoprotein-50 (NHERF-1/ EBP50) to stimulate $\mathrm{Na}(+) / \mathrm{H}(+)$ exchange independent of $\mathrm{G}(\mathrm{i}) / \mathrm{G}(\mathrm{0})$ proteins. J Biol Chem 2004; 279: 25002-9.

15 Chen Y, Chen C, Liu-Chen LY. Dynorphin peptides differentially regulate the human kappa opioid receptor. Life Sci 2007; 80: 143948.

16 Liu-Chen LY. Agonist-induced regulation and trafficking of kappa opioid receptors. Life Sci 2004; 75: 511-36.

17 McLaughlin JP, Myers LC, Zarek PE, Caron MG, Lefkowitz RJ, Czyzyk TA, et al. Prolonged kappa opioid receptor phosphorylation mediated by G-protein receptor kinase underlies sustained analgesic tolerance. J Biol Chem 2004; 279: 1810-8.

18 Meng F, Xie GX, Thompson RC, Mansour A, Goldstein A, Watson SJ, et al. Cloning and pharmacological characterization of a rat kappa opioid receptor. Proc Natl Acad Sci USA 1993; 90: 9954-8.

19 Kreibich A, Reyes BA, Curtis AL, Ecke L, Chavkin C, Van Bockstaele EJ, et al. Presynaptic inhibition of diverse afferents to the locus ceruleus by kappa-opiate receptors: a novel mechanism for regulating the central norepinephrine system. J Neurosci 2008; 28: 6516-25.

20 Shirayama Y, Ishida H, Iwata M, Hazama GI, Kawahara R, Duman RS. Stress increases dynorphin immunoreactivity in limbic brain regions and dynorphin antagonism produces antidepressant-like effects. J neurochem 2004; 90: 1258-68.

21 Winkler CW, Hermes SM, Chavkin Cl, Drake CT, Morrison SF, Aicher SA. Kappa opioid receptor (KOR) and GAD67 immunoreactivity are found in OFF and NEUTRAL cells in the rostral ventromedial medulla. J Neurophysiol 2006; 96: 3465-73.

22 Neugebauer V, Li W, Bird GC, Han JS. The amygdala and persistent pain. Neuroscientist 2004; 10: 221-34.

23 Gutstein HB, Mansour A, Watson SJ, Akil H, Fields HL. Mu and kappa opioid receptors in periaqueductal gray and rostral ventromedial medulla. Neuroreport 1998; 9: 1777-81.

24 Clark CR, Birchmore B, Sharif NA, Hunter JC, Hill RG, Hughes J. PD117302: a selective agonist for the kappa-opioid receptor. $\mathrm{Br} J$ Pharmacol 1988; 93: 618-26.
25 Lahti RA, Mickelson MM, McCall JM, Von Voigtlander PF. $\left[{ }^{3} \mathrm{H}\right]$ U-69593 a highly selective ligand for the opioid kappa receptor. Eur J Pharmacol 1985; 109: 281-4.

26 Hunter JC, Leighton GE, Meecham KG, Boyle SJ, Horwell DC, Rees DC, et al. Cl-977, a novel and selective agonist for the kappa-opioid receptor. Br J Pharmacol 1990; 101: 183-9.

27 Lahti RA, VonVoigtlander PF, Barsuhn C. Properties of a selective kappa agonist, U-50,488H. Life Sci 1982; 31: 2257-60.

28 Pan ZZ. mu-Opposing actions of the kappa-opioid receptor. Trends Pharmacol Sci 1998; 19: 94-8.

29 Mansour A, Hoversten MT, Taylor LP, Watson SJ, Akil H. The cloned mu, delta and kappa receptors and their endogenous ligands: evidence for two opioid peptide recognition cores. Brain Res 1995; 700: 89-98.

30 Land BB, Bruchas MR, Lemos JC, Xu M, Melief EJ, Chavkin C. The dysphoric component of stress is encoded by activation of the dynorphin kappa-opioid system. J Neurosci 2008; 28: 407-14.

31 Schwarzer C. 30 years of dynorphins--new insights on their functions in neuropsychiatric diseases. Pharmacol Ther 2009; 123: 353-70.

32 Day R, Lazure C, Basak A, Boudreault A, Limperis P, Dong W, et al. Prodynorphin processing by proprotein convertase 2 . Cleavage at single basic residues and enhanced processing in the presence of carboxypeptidase activity. J Biol Chem 1998; 273: 829-36.

33 Yakovleva T, Bazov I, Cebers G, Marinova Z, Hara Y, Ahmed A, et al. Prodynorphin storage and processing in axon terminals and dendrites. FASEB J 2006; 20: 2124-6.

34 Shippenberg TS, Zapata A, Chefer VI. Dynorphin and the pathophysiology of drug addiction. Pharmacol Ther 2007; 116: 306-21.

35 Mysels D, Sullivan MA. The kappa-opiate receptor impacts the pathophysiology and behavior of substance use. Am J Addict 2009; 18 : 272-6.

36 Chartoff EH, Potter D, Damez-Werno D, Cohen BM, Carlezon WA Jr. Exposure to the selective kappa-opioid receptor agonist salvinorin $A$ modulates the behavioral and molecular effects of cocaine in rats. Neuropsychopharmacology 2008; 33: 2676-87.

37 Di Chiara G, Imperato A. Drugs abused by humans preferentially increase synaptic dopamine concentrations in the mesolimbic system of freely moving rats. Proc Natl Acad Sci USA 1988; 85: 5274-8.

38 Margolis EB, Hjelmstad GO, Bonci A, Fields HL. Kappa-opioid agonists directly inhibit midbrain dopaminergic neurons. J Neurosci 2003; 23: 9981-6.

39 Ukai M, Mizutani M, Kameyama T. Opioid peptides selective for receptor types modulate cocaine-induced behavioral responses in mice. Nihon Shinkei Seishin Yakurigaku Zasshi 1994; 14: 153-9.

40 Crawford CA, McDougall SA, Bolanos CA, Hall S, Berger SP. The effects of the kappa agonist U-50,488 on cocaine-induced conditioned and unconditioned behaviors and Fos immunoreactivity. Psychopharmacology (Berl) 1995; 120: 392-9.

41 Suzuki T, Shiozaki Y, Masukawa Y, Misawa M, Nagase H. The role of mu- and kappa-opioid receptors in cocaine-induced conditioned place preference. Jpn J Pharmacol 1992; 58: 435-42.

42 Shippenberg TS, LeFevour A, Heidbreder C. kappa-Opioid receptor agonists prevent sensitization to the conditioned rewarding effects of cocaine. J Pharmacol Exp Ther 1996; 276: 545-54.

43 Glick SD, Maisonneuve IM, Raucci J, Archer S. Kappa opioid inhibition of morphine and cocaine self-administration in rats. Brain Res 1995; 681: $147-52$.

44 Negus SS, Mello NK, Portoghese PS, Lin CE. Effects of kappa opioids on cocaine self-administration by rhesus monkeys. J Pharmacol Exp Ther 1997; 282: 44-55.

45 Mello NK, Negus SS. Effects of kappa opioid agonists on cocaine- 
and food-maintained responding by rhesus monkeys. J Pharmacol Exp Ther 1998; 286: 812-24.

46 Schenk S, Partridge B, Shippenberg TS. U69593, a kappa-opioid agonist, decreases cocaine self-administration and decreases cocaine-produced drug-seeking. Psychopharmacology (Berl) 1999; 144: 339-46.

47 Schenk S, Partridge B, Shippenberg TS. Reinstatement of extinguished drug-taking behavior in rats: effect of the kappa-opioid receptor agonist, U69593. Psychopharmacology (Berl) 2000; 151: 85-90.

48 Maisonneuve IM, Archer S, Glick SD. U50,488, a kappa opioid receptor agonist, attenuates cocaine-induced increases in extracellular dopamine in the nucleus accumbens of rats. Neurosci Lett 1994; 181: 57-60.

49 Xu M, Petraschka M, McLaughlin JP, Westenbroek RE, Caron MG, Lefkowitz RJ, et al. Neuropathic pain activates the endogenous kappa opioid system in mouse spinal cord and induces opioid receptor tolerance. J Neurosci 2004; 24: 4576-84.

50 Nakazawa T, Furuya Y, Kaneko T, Yamatsu K. Spinal kappa receptormediated analgesia of E-2078, a systemically active dynorphin analog, in mice. J Pharmacol Exp Ther 1991; 256: 76-81.

51 DeHaven-Hudkins DL, Dolle RE. Peripherally restricted opioid agonists as novel analgesic agents. Curr Pharm Des 2004; 10: 743-57.

52 Pan ZZ, Tershner SA, Fields HL. Cellular mechanism for anti-analgesic action of agonists of the kappa-opioid receptor. Nature 1997; 389: $382-5$.

53 Simonin F, Valverde O, Smadja C, Slowe S, Kitchen I, Dierich A, et al. Disruption of the kappa-opioid receptor gene in mice enhances sensitivity to chemical visceral pain, impairs pharmacological actions of the selective kappa-agonist $\mathrm{U}-50,488 \mathrm{H}$ and attenuates morphine withdrawal. EMBO J 1998; 17: 886-97.

54 Kieffer BL, Gaveriaux-Ruff C. Exploring the opioid system by gene knockout. Prog Neurobiol 2002; 66: 285-306.

55 Aldrich JV, McLaughlin JP. Peptide kappa opioid receptor ligands: potential for drug development. AAPS J 2009; 11: 312-22.

56 Riviere PJ. Peripheral kappa-opioid agonists for visceral pain. $\mathrm{Br} J$ Pharmacol 2004; 141: 1331-4.

57 Stein C, Clark JD, Oh U, Vasko MR, Wilcox GL, Overland AC, et al. Peripheral mechanisms of pain and analgesia. Brain Res Rev 2009; 60: 90-113.

58 Stein C, Lang $\sqcup$. Peripheral mechanisms of opioid analgesia. Curr Opin Pharmacol 2009; 9: 3-8.

59 Binder W, Machelska H, Mousa S, Schmitt T, Riviere PJ, Junien JL, et al. Analgesic and antiinflammatory effects of two novel kappa-opioid peptides. Anesthesiology 2001; 94: 1034-44.

60 Jolivalt CG, Jiang Y, Freshwater JD, Bartoszyk GD, Calcutt NA. Dynorphin A, kappa opioid receptors and the antinociceptive efficacy of asimadoline in streptozotocin-induced diabetic rats. Diabetologia 2006; 49: 2775-85.

61 Ko MC, Tuchman JE, Johnson MD, Wiesenauer K, Woods JH. Local administration of mu or kappa opioid agonists attenuates capsaicininduced thermal hyperalgesia via peripheral opioid receptors in rats. Psychopharmacology (Berl) 2000; 148: 180-5.

62 Barber A, Bartoszyk GD, Bender HM, Gottschlich R, Greiner HE, Harting J, et al. A pharmacological profile of the novel, peripherallyselective kappa-opioid receptor agonist, EMD 61753. Br J Pharmacol 1994; 113: 1317-27.

63 Joshi SK, Su X, Porreca F, Gebhart GF. kappa -opioid receptor agonists modulate visceral nociception at a novel, peripheral site of action. J Neurosci 2000; 20: 5874-9.

64 Wang Y, Tang K, Inan S, Siebert D, Holzgrabe U, Lee DY, et al.
Comparison of pharmacological activities of three distinct kappa ligands (Salvinorin A, TRK-820 and 3FLB) on kappa opioid receptors in vitro and their antipruritic and antinociceptive activities in vivo. J Pharmacol Exp Ther 2005; 312: 220-30.

65 Pfeiffer A, Brantl V, Herz A, Emrich HM. Psychotomimesis mediated by kappa opiate receptors. Science 1986; 233: 774-6.

66 Wadenberg ML. A review of the properties of spiradoline: a potent and selective kappa-opioid receptor agonist. CNS Drug Rev 2003; 9: 187-98.

67 Bals-Kubik R, Ableitner A, Herz A, Shippenberg TS. Neuroanatomical sites mediating the motivational effects of opioids as mapped by the conditioned place preference paradigm in rats. J Pharmacol Exp Ther 1993; 264: 489-95.

68 Mague SD, Pliakas AM, Todtenkopf MS, Tomasiewicz HC, Zhang Y, Stevens WC Jr, et al. Antidepressant-like effects of kappa-opioid receptor antagonists in the forced swim test in rats. J Pharmacol Exp Ther 2003; 305: 323-30.

69 Carlezon WA Jr, Beguin C, DiNieri JA, Baumann MH, Richards MR, Todtenkopf MS, et al. Depressive-like effects of the kappa-opioid receptor agonist salvinorin $A$ on behavior and neurochemistry in rats. J Pharmacol Exp Ther 2006; 316: 440-7.

70 Carlezon WA Jr, Beguin C, Knoll AT, Cohen BM. Kappa-opioid ligands in the study and treatment of mood disorders. Pharmacol Ther 2009; 123: $334-43$.

71 Shippenberg TS, Herz A. Place preference conditioning reveals the involvement of D1-dopamine receptors in the motivational properties of mu- and kappa-opioid agonists. Brain Res 1987; 436: 169-72.

72 Zhang Y, Butelman ER, Schlussman SD, Ho A, Kreek MJ. Effects of the plant-derived hallucinogen salvinorin $A$ on basal dopamine levels in the caudate putamen and in a conditioned place aversion assay in mice: agonist actions at kappa opioid receptors. Psychopharmacology (Berl) 2005; 179: 551-8.

73 Bruchas MR, Land BB, Aita M, Xu M, Barot SK, Li S, et al. Stressinduced p38 mitogen-activated protein kinase activation mediates kappa-opioid-dependent dysphoria. J Neurosci 2007; 27: 11614-23.

74 Sante AB, Nobre MJ, Brandao ML. Place aversion induced by blockade of $\mathrm{mu}$ or activation of kappa opioid receptors in the dorsal periaqueductal gray matter. Behav Pharmacol 2000; 11: 583-9.

75 Redila VA, Chavkin C. Stress-induced reinstatement of cocaine seeking is mediated by the kappa opioid system. Psychopharmacology (Berl) 2008; 200: 59-70.

76 Valdez GR, Platt DM, Rowlett JK, Ruedi-Bettschen D, Spealman RD. Kappa agonist-induced reinstatement of cocaine seeking in squirrel monkeys: a role for opioid and stress-related mechanisms. J Pharmacol Exp Ther 2007; 323: 525-33.

77 Carey AN, Borozny K, Aldrich JV, McLaughlin JP. Reinstatement of cocaine place-conditioning prevented by the peptide kappa-opioid receptor antagonist arodyn. Eur J Pharmacol 2007; 569: 84-9.

78 Beardsley PM, Howard JL, Shelton KL, Carroll FI. Differential effects of the novel kappa opioid receptor antagonist, JDTic, on reinstatement of cocaine-seeking induced by footshock stressors vs cocaine primes and its antidepressant-like effects in rats. Psychopharmacology (Berl) 2005; 183: 118-26.

79 Neumeyer JL, Bidlack JM, Zong R, Bakthavachalam V, Gao P, Cohen DJ, et al. Synthesis and opioid receptor affinity of morphinan and benzomorphan derivatives: mixed kappa agonists and mu agonists/ antagonists as potential pharmacotherapeutics for cocaine dependence. J Med Chem 2000; 43: 114-22.

80 Wang YJ, Tao YM, Li FY, Wang YH, Xu XJ, Chen J, et al. Pharmacological characterization of ATPM [(-)-3-aminothiazolo[5,4-b]-N-cyclopropylmethylmorphinan hydrochloride], a novel mixed kappa-agonist 
and mu-agonist/-antagonist that attenuates morphine antinociceptive tolerance and heroin self-administration behavior. J Pharmacol Exp Ther 2009; 329: 306-13.

81 Gear RW, Miaskowski C, Gordon NC, Paul SM, Heller PH, Levine JD. The kappa opioid nalbuphine produces gender- and dose-dependent analgesia and antianalgesia in patients with postoperative pain. Pain 1999; 83: 339-45.

82 Takemori AE, Loh HH, Lee NM. Suppression by dynorphin A and [desTyr1]dynorphin A peptides of the expression of opiate withdrawal and tolerance in morphine-dependent mice. J Pharmacol Exp Ther 1993; 266: 121-4.

83 Vanderah TW, Gardell LR, Burgess SE, Ibrahim M, Dogrul A, Zhong $\mathrm{CM}$, et al. Dynorphin promotes abnormal pain and spinal opioid antinociceptive tolerance. J Neurosci 2000; 20: 7074-9.

84 Koob GF, Volkow ND. Neurocircuitry of addiction. Neuropsychopharmacology; 35: 217-38.

85 Tao YM, Li QL, Zhang CF, Xu XJ, Chen J, Ju YW, et al. LPK-26, a novel kappa-opioid receptor agonist with potent antinociceptive effects and low dependence potential. Eur J Pharmacol 2008; 584: 306-11.

86 Specker S, Wananukul W, Hatsukami D, Nolin K, Hooke L, Kreek MJ, et al. Effects of dynorphin $\mathrm{A}(1-13)$ on opiate withdrawal in humans. Psychopharmacology (Berl) 1998; 137: 326-32.

87 Greenwald MK, Stitzer ML, Haberny KA. Human pharmacology of the opioid neuropeptide dynorphin A(1-13). J Pharmacol Exp Ther 1997; 281: 1154-63.

88 Trigo JM, Martin-Garcia E, Berrendero F, Robledo P, Maldonado R. The endogenous opioid system: A common substrate in drug addiction. Drug Alcohol Depend 2009; 108: 183-94.

89 Tomasiewicz HC, Todtenkopf MS, Chartoff EH, Cohen BM, Carlezon WA Jr. The kappa-opioid agonist U69,593 blocks cocaine-induced enhancement of brain stimulation reward. Biol Psychiatry 2008; 64:
982-8.

90 Walsh SL, Geter-Douglas B, Strain EC, Bigelow GE. Enadoline and butorphanol: evaluation of kappa-agonists on cocaine pharmacodynamics and cocaine self-administration in humans. J Pharmacol Exp Ther 2001; 299: 147-58.

91 Heidbreder CA, Goldberg SR, Shippenberg TS. The kappa-opioid receptor agonist U-69593 attenuates cocaine-induced behavioral sensitization in the rat. Brain Res 1993; 616: 335-8.

92 Chefer VI, Moron JA, Hope B, Rea W, Shippenberg TS. Kappa-opioid receptor activation prevents alterations in mesocortical dopamine neurotransmission that occur during abstinence from cocaine. Neuroscience 2000; 101: 619-27.

93 Gehrke BJ, Chefer VI, Shippenberg TS. Effects of acute and repeated administration of salvinorin $\mathrm{A}$ on dopamine function in the rat dorsal striatum. Psychopharmacology (Berl) 2008; 197: 509-17.

94 McLaughlin JP, Land BB, Li S, Pintar JE, Chavkin C. Prior activation of kappa opioid receptors by U50,488 mimics repeated forced swim stress to potentiate cocaine place preference conditioning. Neuropsychopharmacology 2006; 31: 787-94.

95 McLaughlin JP, Marton-Popovici M, Chavkin C. Kappa opioid receptor antagonism and prodynorphin gene disruption block stress-induced behavioral responses. J Neurosci 2003; 23: 5674-83.

96 Mello NK, Negus SS. Interactions between kappa opioid agonists and cocaine. Preclinical studies. Ann N Y Acad Sci 2000; 909: 104-32.

97 Archer S, Glick SD, Bidlack JM. Cyclazocine revisited. Neurochem Res 1996; 21: 1369-73.

98 Bowen CA, Negus SS, Zong R, Neumeyer JL, Bidlack JM, Mello NK. Effects of mixed-action kappa/mu opioids on cocaine self-administration and cocaine discrimination by rhesus monkeys. Neuropsychopharmacology 2003; 28: 1125-39. 